РОЗРОБЛЕННЯ СТРАТЕГІЇ ЗАБЕЗПЕЧЕННЯ ЕКОНОМІЧНОЇ БЕЗПЕКИ БУДІВЕЛЬНИХ ПІДПРИЄМСТВ З ВИКОРИСТАННЯМ КОНЦЕПЦІЇ ФРЕЙМІВ

\title{
DEVELOPMENT OF A STRATEGY FOR ENSURING THE ECONOMIC SECURITY OF CONSTRUCTION ENTERPRISES USING THE FRAME CONCEPT
}

Удк 658.338

https://doi.org/10.32843/infrastruct40-84

\section{Фісуненко П.А.}

к.е.н., доцент,

доцент кафедри економіки

та підприємництва

ДВНЗ «Придніпровська державна

академія будівництва та архітектури»

\section{Fisunenko Pavlo}

Prydniprovs'ka State Academy of Civil Engineering and Architecture
В статті наведено результати узагальнення існуючих підходів до формування стратегії забезпечення економічної безпеки підприємств. За результатами огляду та 3 урахуванням сутності економічної безпеки підприємства, передумов ї̈ забезпечення (інноваційної конкурентоспроможності) та сучасних підходів до розроблення стратегій запропоновано в цьому напрямку використовувати концепцію фрреймів. Стратегія представляється у форматі фррейму - структури атрибут-характеристик для опису стратегії забезпечення економічної безпеки будівельного підприємства, що описуються інфрормацією або процедурами, зазначеними в слоті. Слот складається з фасетів, кожен з яких конкретизує інфрормацію, наведену у слоті, у вигляді показників, ситуацій, альтернатив або переліку їх можливих значень. Зазначено, що за таким підходом в стратегічному управлінні з'являється можливість розробити сценарії забезпечення економічної безпеки будівельного підприємства, врахувати ієрархію завдань в процесі досягнення головної мети, не потребується значного масиву цифрової інформації для розробки сценаріїв поведінки підприємства.

Ключові слова: підприємство, економічна безпека, стратегія, забезпечення, фрейм, слот, фрасет.

В статье приведены результаты обобщения существующих подходов к форми - рованию стратегии обеспечения экономической безопасности предприятий. По результатам обзора и с учетом сущности экономической безопасности предприятия, предпосылок ее обеспечения (инновационной конкурентоспособности) и современных подходов к разработке стратегий, предложено в этом направлении использовать концепцию фрреймов. Стратегия представляется в формате фррейма структуры атрибут-характеристик для описания стратегии обеспечения экономической безопасности строительного предприятия, которые описываются инсрормацией или процедурами, указанными в слоте. Слот состоит из фасетов, каждый из которых конкретизирует инсрормацию, приведенную в слоте, в виде показателей, ситуаций, альтернатив или перечня их возможных значений. Отмечено, что при таком подходе в стратегическом управлении появляется возможность разработать сценарии обеспечения экономической безопасности строительного предприятия, учесть иерархию задач в прочессе достижения главной цели, не требуется значительного массива чифровой информации для разработки сценариев поведения предприятия.

Ключевые слова: предприятие, экономи ческая безопасность, стратегия, обеспечение, фррейм, слот, фрасет.

The results of generalization of existing approaches to the formation of strategy for economic security of enterprises have been presented in this article. Based on the results of the review and taking into account the essence of economic security of the enterprise, the prerequisites for its provision (innovative competitiveness) and modern approaches to strategy development, it has been suggested to use the concept of frames in the direction of this research . The strategy is presented in the format of a frame - the structure of attribute-characteristics to describe the strategy of economic security of the construction enterprise, described by the information or procedures specified in the slot. The slot consists of facets, each of which specifies the information provided in the slot in the form of indicators, situations, alternatives or a list of their possible values. It has been noted that this approach in strategic management is an opportunity to develop scenarios for economic security of the construction enterprise, taking into account the hierarchy of tasks in the process of achieving the main goal. It does not require a significant array of digital information to develop scenarios of enterprise behaviour. The components of the strategy of economic security have been described, which is built on the basis of frames - Frame-Position (information on the current situation); Frame-Expectations (a set of ideas about the available opportunities and dangers); Frame-Alternative (choice of type of behaviour and type of strategy); Frame-Offers (possible measures and support tools); Frame-Summary (progress of implementation of security and control measures). The interrelation and content of the elements of the frame strategy for ensuring the economic security of the construction enterprise have been presented. To identify opportunities and dangers in ensuring economic security, it has been suggested to build situational matrices in the projections of the provisioning process. The suggested approach to strategy formation will allow to carry out the constant analysis of levels of economic safety and innovative competitiveness of the construction enterprise, to trace conditions in the building market and external environment as a whole, in the context of realization of the strategic purposes of the enterprise. Key words: enterprise, economic security, strategy, ensurement, frame, slot, facet.

Постановка проблеми. На рівні стратегічного управління вирішуються такі завдання, як аналіз і моделювання дій в певній ситуації, пошук варіантів вирішення стратегічних проблем, підготовка моделей ситуації і врахування характеру фрункціонування підприємства щодо його стійкості до можливих ризиків розвитку подій, підготовка варіантів стратегічної поведінки підприємства.

Беззаперечна необхідність та актуальність розроблення стратегії забезпечення економічної безпеки обумовлюється мінливістю і невизначеністю зовнішнього середовища та необхідністю управління внутрішніми змінними підприємства для досягнення поставленої мети діяльності суб'єкта господарювання.

Аналіз останніх досліджень і публікацій. Питання розроблення стратегії економічної безпеки підприємства наразі активно обговорюються в наукових колах. Базуючись на класичних дослідженнях щодо стратегічного управління, специфіку фрормування стратегій економічної безпеки підприємства розглядають в своїх працях Г. Азаренкова, А. Воронкова, О. Захаров, М. Копитко, Т. Кузенко, О. Марченко, О. Мельник, І. Мойсеєнко, T. Сабецька, В. Сабецький, Н. Сабліна, О. Свірідова, С. Сердечна та інші. Дослідниками 
пропонуються як підходи до трактування поняття стратегії забезпечення економічної безпеки підприємства, так і підходи щодо її розроблення.

Так, за визначенням О. Захарова, «стратегія економічної безпеки підприємства - це довготривалі, найбільш принципові і важливі установки, плани, наміри керівників (власників) підприємства, спрямовані на створення та постійний розвиток системи економічної безпеки, здатної адекватно протидіяти всім внутрішнім та зовнішнім небезпекам і загрозам його стабільної роботи та розвитку в даний час, а також у найближчій та віддаленій перспективах» [6].

Безпосередньо стратегію забезпечення економічної безпеки підприємства автори Г. Азаренкова та С. Сердечна визначають як «загальну стратегію розвитку бізнесу, що включає в себе поточні стратегії переходу підприємства на наступний вищий щабель ієрархії станів економіки, аж до стану «економічна безпека» [4].

О. Мельник дану стратегію трактує як «одну 3 видів фрункціональної стратегії підприємства, яка забезпечує захист його економічних інтересів від різних умов шляхом фрормування довгострокових цілей цього захисту, вибору найбільш ефективних шляхів їх досягнення, адекватного корегування напрямків і фрорм захисту при зміні чинників і умов економічного середовища його фрункціонування» [8].

І. Мойсеєнко та О. Марченко [9] визначають відповідну стратегію як створення плану довгострокових дій, котрі могли би забезпечити досягнення основної мети, яку ставить перед собою підприємство, за допомогою реалізації цілей та завдань.

Як «комплекс дій, що дають можливість чітко виявити та означити основні пріоритети подальшої діяльності підприємства в аспекті забезпечення економічної безпеки, беручи до уваги змінність та нестабільність умов зовнішнього та внутрішнього середовища його існування» розглядає стратегію забезпечення економічної безпеки підприємства М. Копитко [7].

Серед всього різноманіття підходів до розробки стратегії забезпечення економічної безпеки, слід виділити сучасні підходи. Зокрема, автори А. Воронкова та О. Свірідова на основі праць закордонних вчених [1; 2] пропонують при розробці стратегії забезпечення економічної безпеки підприємства використовувати сценарний підхід [5]. Дослідники Н. Сабліна та Т. Кузенко пропонують використовувати концепцію розробки «стратегічних карт», що «сприяє реалізації стратегії підприємства в галузі забезпечення оптимального рівня його фрінансової безпеки, забезпечує керівництво якісною інформацією, необхідною для прийняття обґрунтованих управлінських рішень, є інструментом забезпечення виконання довгострокової стратегії підприємства» [11]. Учені Т. Сабецька та
В. Сабецький при фрормуванні стратегії економічної безпеки підприємства пропонують комплексний методичний підхід, «у рамках якого плануються заходи щодо захисту бізнесу від зовнішніх та внутрішніх загроз, розробляються організаційно-економічні механізми системи економічної безпеки, а також їі ресурсне, кадрове, організаційне та фрінансове забезпечення [10].

Віддаючи належне існуючим працям, вважаємо, що потребують подальшого вдосконалення підходи до розробки зазначеної стратегії, які б забезпечили досягнення будівельним підприємством успіху в мінливому зовнішньому середовищі за рахунок підвищення інноваційної конкурентоспроможності як основної передумови фрормування належного рівня економічної безпеки.

Постановка завдання. Враховуючи напрацювання щодо розуміння сутності економічної безпеки підприємства, передумов ії забезпечення та сучасних підходів до розроблення стратегій, метою дослідження буде розробка підходу до фрормування стратегії забезпечення економічної безпеки будівельного підприємства на основі концепції фрреймів.

Виклад основного матеріалу дослідження. Для успішності реалізації стратегічного управління процесом забезпечення економічної безпеки будівельного підприємства, що залежить від уміння адекватно визначати відповідність досягнутих результатів поставленим цілям та розробляти стратегію забезпечення економічної безпеки будівельного підприємства, нами пропонується використати концепцію фреймів.

Марвін Мінські, як автор концепції орреймів, в своїй роботі [3] визначив фррейм як «структуру даних для представлення певних ситуацій». Цю структуру він наповнив найрізноманітнішою інорормацією: про об'єкти і події, які слід очікувати в цій ситуації, і про те, як використовувати інформацію, наявну у орреймі.

Згідно цієї концепції, стратегію необхідно представити у форматі фррейму (англ. frame - «каркас», «рамка») - структури слотів, що описують процес забезпечення економічної безпеки будівельного підприємства тадеталізуються за допомогою фасетів щодо можливих варіантів поведінки на будівельному ринку, визначених на основі когнітивного пізнання ринку як середовища фрункціонування.

Тобто оррейм - це структура атрибут-характеристик для опису стереотипної ситуації (у нашому випадку - стратегії забезпечення економічної безпеки будівельного підприємства як комплексу стрижневих питань, що стосуються цього процесу), що складається 3 характеристик цієї ситуації або їх значень. Ці атрибут-характеристики описують інформацію або процедури, зазначені в слоті. При цьому слот включає компоненти, які називаються фрасетами, кожен з яких конкретизує інформацію, 
наведену у слоті, у вигляді показників, ситуацій, альтернатив або переліку їх можливих значень.

Переваги підходу до формування стратегії, заснованої на фрреймах, полягають в тому, що концепція фрреймів в стратегічному управлінні певним чином дає можливість розробити сценарії забезпечення економічної безпеки будівельного підприємства та інтегрується 3 ієрархічним поданням процесу досягнення головної мети підприємства і не потребує значного масиву цифрової інфрормації для розробки сценаріїв поведінки підприємства.

Першим фрреймом стратегії забезпечення економічної безпеки є Фрейм-Позиція, який $є$ сукупністю інфрормації щодо поточної ситуації, що склалась, та відбиває досягнутий підприємством та його конкурентами рівні економічної безпеки та інноваційної конкурентоспроможності.

Фрейм-Очікування є другим фрреймом стратегії забезпечення економічної безпеки, який є сукупністю уявлень будівельного підприємства про наявні в нього можливості та небезпеки, генеровані можливими діями як самого підприємства, так і підприємств-конкурентів, відображенням яких $€$ ситуативні матриці забезпечення економічної безпеки за різними сценаріями, що характеризуються певними показниками. Зважаючи на те, що аналіз показників забезпечення економічної безпеки є досить багатокомпонентним та його результати (що в кількісному вигляді дозволяють оцінити сукупність можливостей/небезпек, які відповідають кожному сценарію в конкретній ситуації) потребують систематизації на проекції, яким відповідають певні показники, пропонуємо використати наступні проекції забезпечення економічної безпеки (рис. 1).
Всі показники забезпечення економічної безпеки можна поділити на наступні проекції процесу забезпечення економічної безпеки будівельного підприємства, які відповідають певним варіаціям ситуативної матриці:

- першим показником $є$ рівень економічної безпеки, який відбиває цільову проекцію процесу забезпечення економічної безпеки, адже у абсолютному вигляді свідчить про досягнення чи недосягнення поставленої мети даного процесу;

- другий та третій показники є відносними та безпосередньо стосуються потенціалу економічної безпеки та інноваційної конкурентоспроможності. При цьому ці показники відбивають різні проекції процесу забезпечення економічної безпеки. Показник потенціалу економічної безпеки відображає базову проекцію процесу її забезпечення, адже характеризує досягнутий відрив підприємства-лідера від конкурентів за потенціалом забезпечення економічної безпеки. Показник потенціалу інноваційної конкурентоспроможності відбиває функціональну проекцію процесу забезпечення економічної безпеки, адже завдяки компліментарному зв'язку, що існує між економічною безпекою та рівнем конкурентоспроможності, підвищення рівня інноваційної конкурентоспроможності створює зростаючі можливості для збільшення рівня економічної безпеки підприємства;

- четвертим показником $\epsilon$ імовірність змін у фрункціонуванні будівельного підприємства, що відображає ризик-проекцію процесу забезпечення його економічної безпеки.

Можливість наочно представити в узагальненому вигляді результати такого аналізу надає матричний метод, зокрема побудова ситуативної

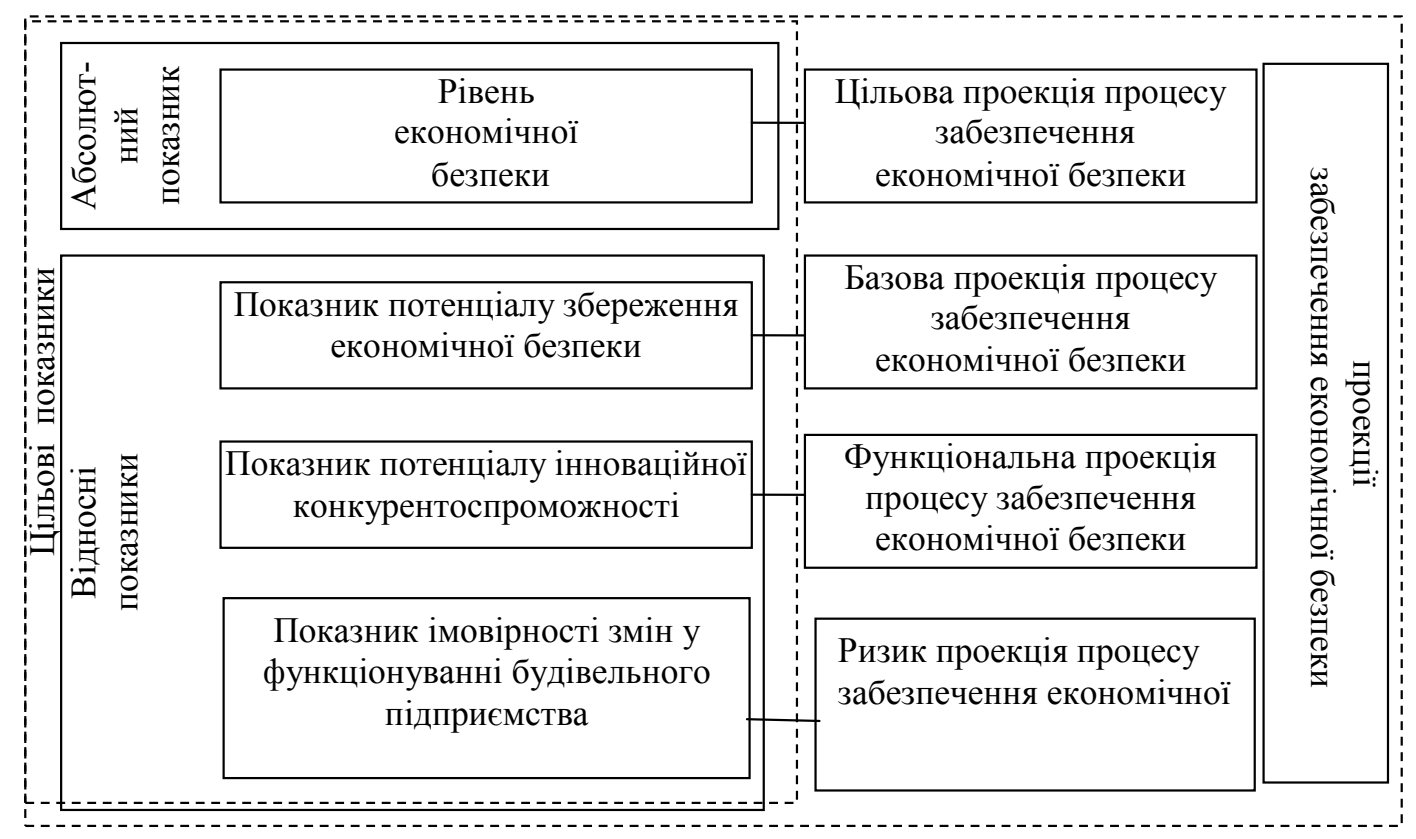

Рис. 1. Проекції процесу забезпечення економічної безпеки будівельного підприємства 
Шаблон ситуативної матриці забезпечення економічної безпеки (цільова проекція)

Таблиця 1

\begin{tabular}{|c|c|c|c|c|}
\hline \multirow{3}{*}{ 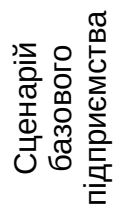 } & Форсуючий & $E \sigma^{0 / \max }$ & $E Б^{\min / \max }$ & $E Б^{\max / \max }$ \\
\hline & Зважений & $E 5^{\text {o/min }}$ & $E 5^{\min / m i n}$ & $E 5^{\text {max }}{ }^{\text {min }}$ \\
\hline & Апатичний & $E 5^{\circ / 0}$ & $E 5^{\mathrm{min} / 0}$ & $E 5^{\max / 0}$ \\
\hline & & Апатичний & Зважений & Форсуючий \\
\hline
\end{tabular}

матриці забезпечення економічної безпеки в цільовій проекції, що дозволяє визначити, яким при кожному ситуативному збігу буде показник рівня економічної безпеки (табл. 1). Подібні ситуативні матриці необхідно будувати у різних проекціях (згідно рис. 1).
Результати розрахунків у ситуативних матрицях $€$ основною інфрормацією третього фррейму стратегії забезпечення економічної безпеки, яким $€$ Фрейм-Альтернатива.

Фрейм-Альтернатива $€$ сукупністю інсрормації про наявний у підприємства вибір щодо типу

\section{ЕЛЕМЕНТИ СТРАТЕГІЇ ЗАБЕЗПЕЧЕННЯ ЕКОНОМІЧНОЇ БЕЗПЕКИ}

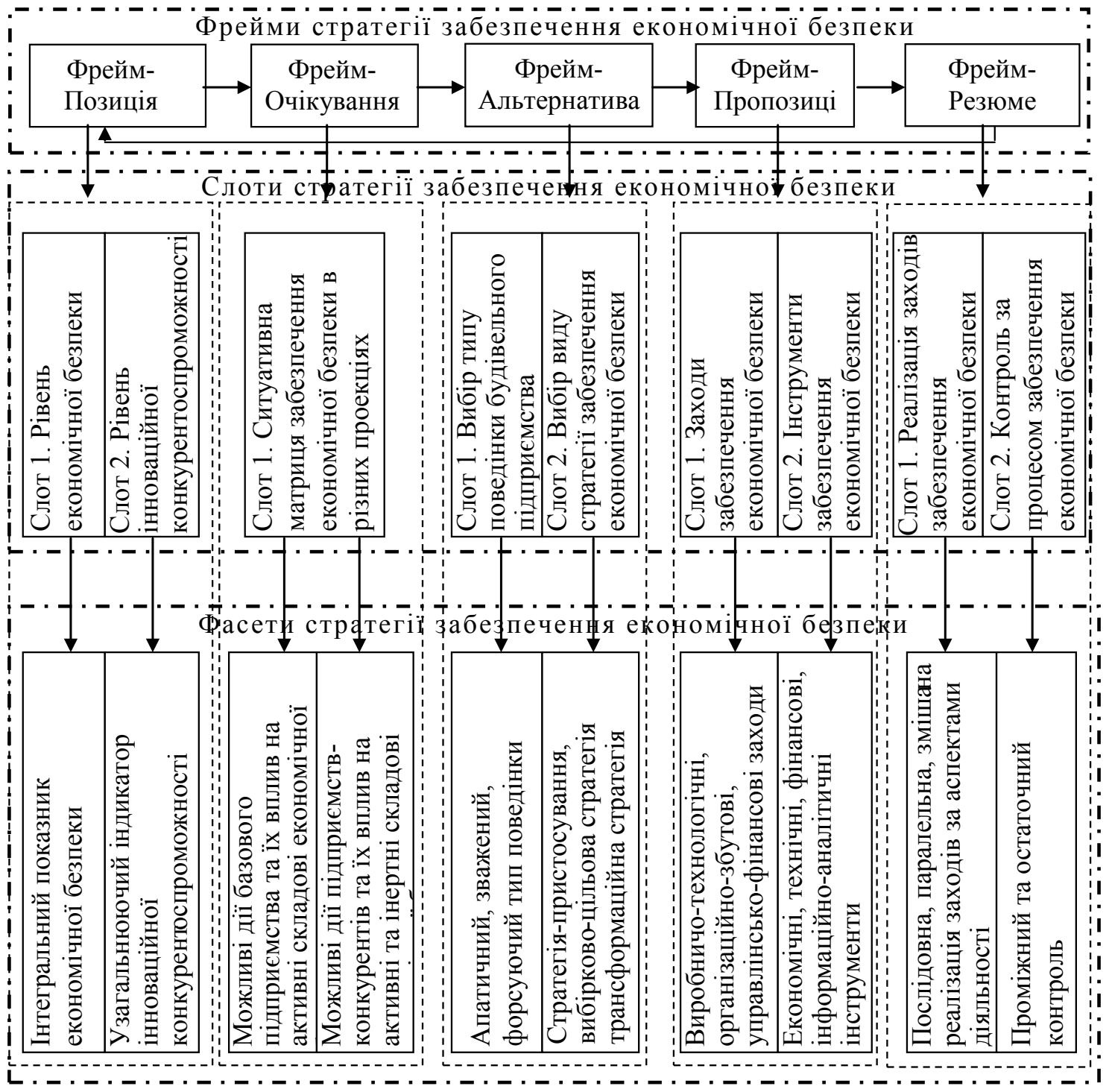

Рис. 2. Елементи фрейм-стратегії забезпечення економічної безпеки будівельного підприємства 
подальшої поведінки (апатичного, зваженого або форсуючого) та виду стратегії (стратегія-пристосування, вибірково-цільова стратегія, трансорормаційна стратегія), якої воно має дотримуватися.

Четвертим фрреймом стратегії забезпечення економічної безпеки будівельного підприємства $€$ Фрейм-Пропозиції, який є сукупністю інфрормації про виробничо-технологічні, організаційно-збутові, управлінсько-фрінансові заходи забезпечення економічної безпеки та інструменти, які при реалізації даних заходів мають застосовуватись.

Інструменти забезпечення економічної безпеки, які описуються в четвертому фреймі, представляють стандартний перелік економічних, технічних, фрінансових та інформаційно-аналітичних інструментів, серед яких кожне окреме будівельне підприємство може сорормувати свій набір та змінювати його залежно від перебігу подій, у випадку неефективності обраних інструментів.

Останнім фрреймом стратегії забезпечення економічної безпеки є Фрейм-Резюме, який відбиває інфрормацію про хід реалізації заходів забезпечення економічної безпеки та інфрормацію щодо способів та видів контролю за цим процесом. Причому, хід реалізації заходів може бути послідовним, паралельним або змішаним. щодо контролю за процесом забезпечення економічної безпеки, то він $\epsilon$ проміжним та остаточним. Причому, на етапі проміжного контролю проводиться аналітична оцінка правильності вибору та дієвості заходів забезпечення економічної безпеки. Якщо інформація проміжного контролю задовольняє запланованим результатам, то процес реалізації заходів продовжується і після його завершення здійснюється остаточний контроль отриманих результатів.

В підсумку, інфрормація, що міститься у ФреймРезюме, дозволяє завершити реалізацію розробленої стратегії та починати новий цикл процесу забезпечення економічної безпеки.

Для унаочнення вищенаведеної інформації, розроблена стратегія забезпечення економічної безпеки будівельного підприємства, що складається з фреймів, представлених сукупністю слотів, кожному з яких відповідають фрасети забезпечення економічної безпеки, зображена у вигляді наступної схеми (рис. 2).

Запропонована фррейм-стратегія є продуктом постійного аналізу рівнів економічної безпеки та інноваційної конкурентоспроможності будівельного підприємства та моніторингу як умов функціонування, що фрормуються на будівельному ринку, так і зовнішнього середовища в цілому, в контексті реалізації окреслених стратегічних цілей цього підприємства. Терміни її реалізації не обмежуються, а лише корегуються її елементи за необхідності.

Висновки 3 проведеного дослідження. За такого підходу, стратегія забезпечення економічної безпеки будівельного підприємства якнайкраще виконуватиме роль послідовного, конструктивного, раціонального, стійкого до умов функціонування, стратегічного плану, реалізація якого скерована на досягнення будівельним підприємством успіху в мінливому зовнішньому середовищі за рахунок підвищення рівня його інноваційної конкурентоспроможності та економічної безпеки.

\section{БІБЛІОГРАФІЧНИЙ СПИСОК:}

1. James A. Ogilvy. Creating Better Futures: Scenario Planning as a Tool for a Better Tomorrow. Oxford University Press, 2002. 238 p.

2. Kees van der Heijen. Scenarios, Strategies and the Strategy Process. Nijenrode University Press, 1997. 33 p.

3. Marvin Minsky. A Framework for Representing Knowledge. MIT-Al Laboratory Memo 306, June, 1974. URL: https://web.media.mit.edu/ minsky/papers/ Frames/frames.html (дата звернення 21.10.2019).

4. Азаренков Г.Ф., Сердечна С.М. Формування аналітичного інструментарію забезпечення економічної безпеки стратегічного розвитку підприємства. Молодий вчений. 2017. №5 (45). С. 508-517.

5. Воронкова А.Е., Свірідова О.В. Сценарний підхід до вибору стратегії забезпечення економічної безпеки експортної діяльності підприємства. Вісник Хмельницького національного університету. 2009. № 4, T. 1. C. 96-99.

6. Захаров О.І. Стратегія економічної безпеки підприємства. Науковий вісник Львівського державного університету внутрішніх справ. 2012. № 2. C. 272-282.

7. Копитко М.I. Комплексне забезпечення економічної безпеки підприємства (на матеріалах підприємств транспортного машинобудування) : дис. ... д-ра екон. наук : 21.04.02 / ВН3 «Університет економіки і права «КРОК». Київ, 2015. 478 с.

8. Мельник О.О. Сутність розробки стратегії забезпечення економічної безпеки автотранспортного підприємства. Комунальне господарство міст. 2012. №106. C. 276-282.

9. Мойсеєнко І.П., Марченко О.М. Управління фрінансово-економічною безпекою підприємства : навч. посіб. Львів, 2011. 380 с.

10. Сабецька Т.І., Сабецький В.Б. Теоретичні засади стратегічного планування економічної безпеки підприємства. Вісник Одеського національного універcumemy. Серія : Економіка. 2019. Вип. 2, Т. 24. С. 49-55.

11. Сабліна Н. В., Кузенко Т. Б Формування стратегічних карт у рамках реалізації процесу управління фрінансовою безпекою підприємства Бізнесінфрорм. 2013. № 4. C. 326-331.

\section{REFERENCES:}

1. James A. Ogilvy (2002) Creating Better Futures: Scenario Planning as a Tool for a Better Tomorrow. Oxford University Press.

2. Kees van der Heijen (1997) Scenarios, Strategies and the Strategy Process. Nijenrode University Press.

3. Marvin Minsky (1974) A Framework for Representing Knowledge. MIT-AI Laboratory Memo, no. 306. Availiable at: https://web.media.mit.edu/ minsky/papers/ Frames/frames.html (accessed 21.10.2019). 
4. Azarenkov G. F., Serdechna S. M. (2017) Formuvannja analitychnogo instrumentariju zabezpechennja ekonomichnoi bezpeky strategichnogo rozvytku pidpryjemstva [Formation of analytical tools to ensure economic security of strategic development of the enterprise]. Molodyj vchenyj, no. 5 (45), pp. 508-517.

5. Voronkova A. E., Sviridova O. V. (2009) Scenarnyj pidhid do vyboru strategii zabezpechennja ekonomichnoi bezpeky eksportnoi dijalnosti pidpryjemstva [Scenario approach to the choice of strategy for economic security of export activities of the enterprise]. Visnyk Hmelnyckogo nacionalnogo universytetu, vol. 1, no. 4, pp. 96-99.

6. Zaharov O. I. (2012) Strategija ekonomichnoi bezpeky pidpryjemstva [The strategy of economic security of the enterprise]. Naukovyj visnyk Lvivskogo derzhavnogo universytetu vnutrishnih sprav, no. 2, pp. 272-282.

7. Kopytko M. I. (2015) Kompleksne zabezpechennja ekonomichnoi bezpeky pidpryjemstva (na materialah pidpryjemstv transportnogo mashynobuduvannja) [Complex provision of economic safety of the enterprise (on materials of the enterprises of transport engineering)]. (Doctoral thesis). Kyiv: Universytet ekonomiky i prava «KROK».
8. Melnyk O. O. (2012) Sutnist rozrobky strategii zabezpechennja ekonomichnoi bezpeky avtotransportnogo pidpryjemstva [The essence of developing a strategy to ensure the economic security of the transport company]. Komunalne gospodarstvo mist, no. 106, pp. 276-282.

9. Mojsejenko I. P., Marchenko O. M. (2011) Upravlinnja finansovo-ekonomichnoju bezpekoju pidpryjemstva [Management of financial and economic security of the enterprise]. Lviv. (in Ukrainian)

10. Sabecka T. I., Sabeckyj V. B. (2019) Teoretychni zasady strategichnogo planuvannja ekonomichnoi bezpeky pidpryjemstva [Theoretical principles of strategic planning of economic security of the enterprise]. Visnyk Odeskogo nacionalnogo universytetu. Serija : Ekonomika, vol. 24, no. 2, pp. 49-55.

11. Sablina N. V., Kuzenko T. B. (2013) Formuvannja strategichnyh kart u ramkah realizacii procesu upravlinnja finansovoju bezpekoju pidpryjemstva [Formation of strategic maps in the implementation of the process of managing the financial security of the enterprise]. Biznesinform, no. 4, pp. 326-331. 